The Nuclear Reactor

By Dr. Alan Salmon. (Methuen's Monographs on Physicel Subjects.) Pp. 144. (London: Methuen and Co., Ltd.; New York: John Wiley and Sons, Inc., 1964.) 16s. net. THE Nuclear Reactor has been produced for honours $l$ physics students, postgraduate students of nuclear power and for the non-physicist whose work is associated with nuclear power.

The introductory chapter is followed by chapters covering nuclear fission, the basic theory of neutron behaviour, and the optimum use of fuel and neutron flux flattening. There is a useful chapter on heat transfer, which includes a brief account of the desirable features of reactor coolants. Reactor control and shielding are then considered, followed by a chapter on the reactor as a source of radiation. This includes a description of the basic kinds of research reactors and their characteristics. The final chapter is concermed with future developments, and discusses in some detail the future of nuclear power reactors.

Throughout the book, emphasis is placed on understanding the processes and methods involved. Each chapter has its own set of references and a useful list of suggested further reading. The graphs and drawings are distinct and adequately annotated, and fit well into the text.

For such a compact book the subject of nuclear reactors is soundly treated, though because of its size the book does suffer through its inability to spend enough time on detail. However, the aim of the book-a short succinct account of nuclear reactors-is quite well achieved, and though there are other similar books it should find a welcome place on many bookshelves.

V. S. CROCKER

\section{Progress in Medicinal Chemistry}

Vol. 4. Edited by G. P. Ellis and G. B. West. Pp. ix + 221. (London: Butterworth and Co. (Publishers), Ltd., 1965.) 67s. 6d.

$\mathrm{V}$ OLUME 4 of Progress in Medicinal Chemistry, like its predecessors, is a series of review articles. Barnes and Paget, writing on drug toxicity, highlight our remarkable lack of knowledge of the nature of the majority of toxic responses. When so much effort is expended in the production of new drugs, present knowledge of the biochemistry of the toxic response seems disproportionately small. This article merits classification as compulsory reading for all those interested either in the production or in the application of new drugs. The difficult subject of drug receptor interactions is surveyed by Gill with particular emphasis on the shapes of small molecules and on their interaction with proteins. In this rapidly developing field, recent investigations on allosteric enzymes are likely to have a considerable impact. The comprehensive review by Law of recent work on biologically active peptides emphasizes the remarkable progress made during the past ten years. The volume is completed by an article on analgesics (Beckett and Casy) and by one on experimental hypersensitivity (Spencer and West). As might be expected in such a composite volume, the standard achieved varies considerably, but nevertheless there is sufficient thought in some parts of this volume to make it desirable reading. T. S. Work

\section{Experiments in Plant Hybridization}

By G. Mendel. Pp. ix +95. (Edinburgh and London: Oliver and Boyd, Ltd., 1965.) $21 s$.

$\checkmark$ THIS is a pleasing little volume appropriate both for the Mendel centenary and as a contribution to the memory of Fisher. It contains more than its title suggests, for within its covers we find Fisher's notable essay on the history of science, Fisher's notes on Mendel's paper and Bateson's biography of Mendel, in addition to Bateson's translation of Mendel's paper.

There is little for me to say except to congratulate both editor and publisher. However, a reading of the book prompts a question of some historical interest. Most outstanding science involves not only imaginative ability and painstaking work, but also an element of luck. One remark in Mendel's paper, taken together with Bateson's footnote, suggests an element of luck that has not, so far as I am aware, been noted before. This is that Pisum was in fact self-pollinating. Mendel states dogmatically that "It is only in the Leguminosae, like Pisum, Phaseolus and Lens, whose organs of fertilisation are protected by the keel", that numerous varieties maintain "a stability as great as that of species growing in the wild". Bateson comments that "Phaseolus is neverthelessinsect fertilised".

Now Vilmorin ${ }^{1}$ carried out experiments from 1856-60 with Lupinus hirsutus which were not dissimilar to some of Mendel's and based his interpretations on the same dogma that "comme dans beaucoup de légumineuses papilionacées, la fécondation s'y opère généralement à huis-clos et sans l'intervention d'aucun insecte". But one only has to glance at his data with hind-sight to see that he was getting dominant progeny from recessives as well as vice versa, hence that considerable outcrossing was going on.

There may therefore have been an element of luck in Mendel's choice of Pisum rather than Phaseolus for the bulk of his work. However, though Mendel nowhere throws doubt on the accepted dogma as applied to Phaseolus, he designed his experiments with Pisum so that he would know if occasional uncontrolled crossing did occur. In other words, though he may have been somewhat lucky in choosing Pisum, he would not have been misled had he chosen Phaseolus, for though he does not doubt the accepted he made sure it really did apply to his material.

These comments of mine merely illustrate the way in which this book can provoke thought about the factors involved in good experimentation. It should be widely read by biologists and historians of science, and should be in all school libraries. It is not only a document on the foundation of genetics, but a valuable education in the anatomy of experimental science. J. M. THODAY

${ }^{1}$ See the paper on his father's experiments by Vilmorin, H. (Sociéte National d'Agriculture de France, Paris, 1879).

\section{Administering Research and Development}

The Behaviour of Scientists and Engineers in Organizations. By Charles D. Orth, Prof. Joseph C. Bailey and Francis W. Wolek, Pp. $\mathrm{x}+585$. (London: Tavistock Publications, Ltd., 1965.) 50s. net.

THE organizational and human problems involved in the management and control of large-scale research and development have received considerable attention during recent years. The most thorough exposition of them in Britain, in relation to Government departments and other bodies financed wholly by the Exchequer, was afforded by the Gibb-Zuckerman report published by H.M.S.O. in 1961. This American book describes the results of a six-year investigation into the behaviour of scientists and engineers employed within industrial research and development establishments. It records case studies conducted in fourteen such establishments covering a wide spectrum of industrial activity, and contains a number of research reports dealing generally with the issues raised by these studies. It includes also a series of so-called conceptional readings which seek to illuminate, from different points of view, the factors affecting behaviour in the environment of research and development work. Perhaps inevitably, a book so composed and on a subject of such complexity is not easily digestible, and the reading and understanding of it would have been assisted had it contained an extraction of a number of common occurrences of general relevance to the situations examined, which could serve as guide-lines for those carrying senior responsibility in the research and develop. ment field.
WIILIS JACKSON 